\title{
Perancangan dan Implementasi Desain Kendaraan Listrik Konsep Urban Dengan Penggerak BLDC 1000 Watt
}

\author{
Jatmiko, Abdul Basith, Agus Ulinuha, Ibnu Shokhibul Khak, Dimas Septian Dwi Putra. \\ Teknik elektro, Fakultas Teknik \\ Universitas Muhammadiyah Surakarta \\ Sukoharjo, Indonesia \\ jat244@ums.ac.id
}

\begin{abstract}
Abstraksi - Penelitian ini bertujuan untuk mendapatkan suatu desain kendaraan listrik konsep urban yang efisien dalam hal konsumsi energi, kemudian desain tersebut dilakukan pengimplementasian, komponen-komponen yang dirancang dan dimplementasikan meliputi sasis dengan bahan dasar alumunium alloy yang disatukan dengan las dan rivet, sistem penggerak menggunakan motor BLDC 1000 watt, dan baterai dengan jenis cell lithium-ion dengan tegangan 48 volt 8,7 ampherehour dilengkapi dengan battery management system, kemudian dilakukan proses perakitan semua komponen dari implementasi desain kendaraan listrik sehingga didapat luaran kendaraan listrik yang utuh .
\end{abstract}

Katakunci —Efisiensi; Mobil Listrik; Baterai Lithium-Ion; Motor BLDC

Abstracts - This study aims to obtain an urban concept electric vehicle design that is efficient in terms of energy consumption, then the design is implemented, the components are designed and implemented include the chassis with aluminum alloy base material which is integrated with welding and rivet, the drive system uses a BLDC motor 1000 watts, and batteries with lithium-ion cell type with a voltage of 48 volts 8.7 ampherehour equipped with a battery management system, then the assembly process of all components of the implementation of the design of electric vehicles is carried out in order to obtain a complete electric vehicle output as well.

\section{Keywords — Efficiency; Electric Cars; Lithium-Ion Batteries; BLDC Motors}

\section{PENDAhuluan}

Krisis bahan bakar minyak ( BBM ) semakin mengancam keberlangsungan hidup manusia khusunya dalam sektor transportasi seperti mobil, sepeda motor, bus, dan lain lain. Dapat dilihat dari data dari Badan Pusat Statistik (BPS) Nasional [1], jumlah kendaraan bermotor roda empat aatu lebih yang berada pada akhir 2017 yaitu 25.525.876 unit dan tentunya hal ini akan selalu bertambah setiap tahunnya. Hal ini tentunya akan berbanding lurus dengan penggunaan BBM yang semakin meningkat, dapat kita lihat dari data $\mathrm{BPH}$
MIGAS tahun 2017[2] ,bahwa konsumsi BBM sebesar 55.400.604,901 liter. Efek samping dari penggunaan kendaraan berbahan bakar minyak adalah dapat menyebabkan polusi udara, hasil dari emisi gas buang pembakaran BBM. Oleh karena itu perlu diadakannya penelitian berkaitan kendaraan dengan tenaga listrik yang memiliki efisiensi tinggi, untuk mengurangi penggunaan BBM yang masih sangat banyak di Indonesia. Salah satu usahanya adalah diadakannya penelitian ini, yaitu perancangan dan implementasi desain kendaraan mobil listrik konsep urban, dengan tujuan untuk mengimplementasikan kendaraan dengan tenaga listrik dengan tingkat efisien yang tinggi pada mobil konsep urban. Salah satu hasil yang diharapkan dari penelitian ini adalah penggunaan tenaga listrik yang efisien dan mobil konsep urban yang dibuat, dapat mengikuti Kontes Mobil Hemat Energi pada tahun 2019 (KMHE 2019).

\subsection{Sasis}

sasis mobil pada awalnya terpisah dengan body, keduanya adalah hal terpisah, Sasis memberi dasar kekuatan kendaraan. Belakangan ini body dan sasis sudah digabung jadi monocoque setiap bagian, serta dapat menghasilkan banyak kendaraan yang lebih ringan. Baik monocoque atau sasis / unit body yang terpisah merupakan dasar yang dapat diterima untuk desain. Terlepas dari popularitas monocoque, beberapa kendaraan listrik modern menggunakan sasis terpisah[3].

\subsection{Sistem Penggerak}

penggerak utama adalah mesin yang mengubah bahan bakar menjadi pekerjaan yang bermanfaat[4], dalam hal ini sistem penggerak tersebut mengubah energi kimia yang tersimpan pada baterai dikonversi menjadi gerak putar untuk memutar roda kendaraan. Banyak mobil listrik memiliki akselerasi yang lebih tinggi daripada mobil pembakaran internal rata-rata, sebagian besar disebabkan oleh berkurangnya kerugian gesekan drivetrain, dan torsi yang lebih cepat tersedia dari motor listrik[5]. 


\subsection{Baterai Lithium-Ion}

Sebagian besar baterai lithium dilengkapi dengan beberapa jenis sistem manajemen baterai (BMS). Ini adalah sistem yang mengatur pengisian dan keseimbangan tegangan baterai. Semua baterai lithium memerlukan BMS, Lithium baterai dirancang untuk beroperasi dengan aman di dalam tegangan operasi normal, tetapi baterai menjadi tidak stabil jika dibebankan pada tegangan yang lebih tinggi di atas ambang batas yang dirancang. Jika dibiarkan tanpa pengawasan, sel dapat melepaskan gas yang mudah terbakar, dan memicu baterai didekatnya, menyebabkan reaksi berantai. Baterai lithium dapat meledak jika kepanasan atau jika diisi dengan baterai tegangan terlalu tinggi[6].

\subsection{Motor BLDC}

Motor DC brushed ditemukan pada abad ke-19 . Motor DC brushless dimungkinkan oleh pengembangan elektronik solid state di tahun 1960-an[7]. Motor DC tanpa sikat merupakan motor yang memiliki efisiensi baik, lebih handal, umur lebih panjang dan murah. Motor ini memiliki bagian rotor berupa magnet permanen dan bagian stator berupa belitan untuk menghasilkan medan magnet. Pengubahan polaritas motor BLDC dilakukan secara elektronik menggunakan sensor halleffect dan rotary encoder. Karena itu pemanfaatannya pada sepeda motor listrik hampir bebas perawatan, tidak membutuhkan minyak, busi baru atau perbaikan rutin lainya seperti yang dilakukan motor bakar[8].

\section{METODE}

Tahapan penelitian ini diuraikan metodologinya meliputi tahap persiapan, tahap perancangan, dan tahap pengimplementasian sebagai berikut :

\subsection{Tahap persiapan}

Persiapan dilakukan dengan cara benchmarking kendaraan listrik konsep urban dari perguruan tinggi lain yang sudah lebih dahulu melakukan riset pada bidang kendaraan listrik, kemudian data-data berdasarkan hasil peninjauan langsung tersebut dijadikan acuan rencana desain agar didapat hasil yang minim kesalahan perancangan.

\subsection{Tahap perancangan}

Perancangan meliputi komponen-komponen utama dari suatu kendaraan listrik, diantaranya adalah rancangan sasis, body, sistem penggerak, dan baterai :

\subsubsection{Perancangan sasis}

Memanfaatkan platform software simulasi solidwork sehingga didapat dimensi dan jenis material yang dipakai pada sasis kendaraan listrik konsep urban.

\subsubsection{Perancangan sistem penggerak}

Sistem penggerak terdiri dari pedal injak, pengendali dan menggunakan motor bldc yang telah disesuaikan dengan kebutuhan beban yang dipikul keseluruhan kendaraan.

\subsubsection{Perancangan baterai}

Terdapat beberapa tipe baterai di pasaran, pada penelitian ini menggunakan jenis baterai lithium-ion dimana memiliki keunggulan cukup ringan dibanding dengan jenis baterai lain dengan kapasitas yang sama, namun jenis baterai yang terdiri dari banyak jenis cell ini perlu perangkat tambahan, yaitu battery management system (BMS).

\subsection{Tahap pengimplementasian}

Pengimplementasian dilakukan setelah masing-masing rancangan komponen telah matang dan siap untuk dilakukan aktifitas produksinya, meliputi sasis, sistem penggerak dan baterai, setelah itu dilakukan pengujian secara keseluruhan seperti yang ditunjukan gambar 1 .

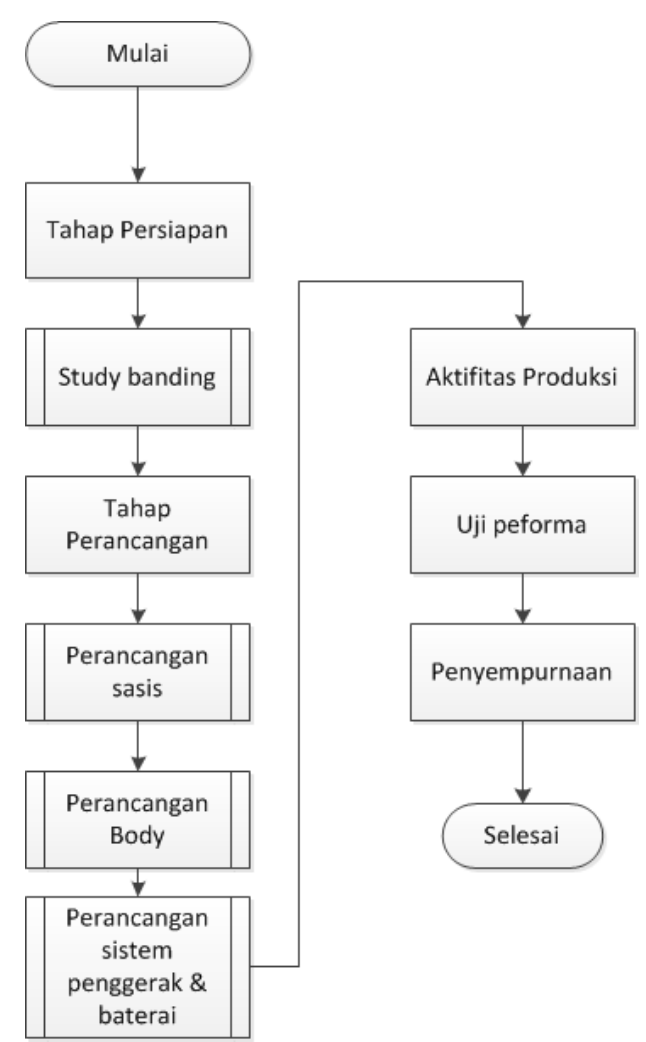

Gambar 1. Alur Penelitian.

\section{HASIL DAN PEMBAHASAN}

Perancangan dan implementasi kendaraan listrik konsep urban menghasilkan beberapa rancangan desain beserta 
pengimplementasianya yang akan dijelaskan pada sebagai berikut.

\subsection{Sasis}

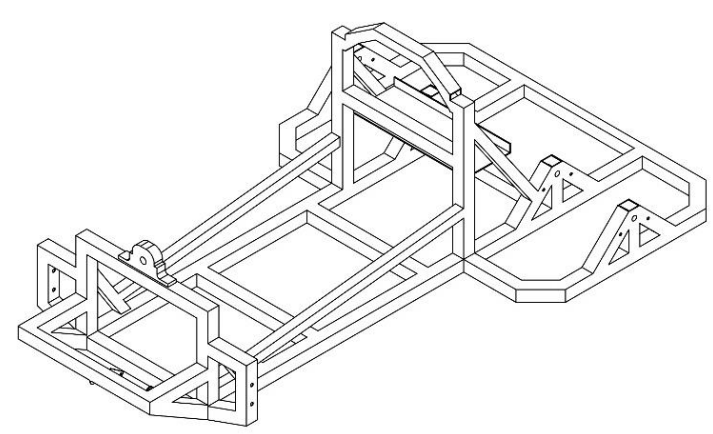

Gambar 2. sasis dengan model 3D

Gambar 2 memperlihatkan bentuk model sasis ditampilkan dalam 3 dimensi. pembuatan desain gambar menggunakan software solidwork sehingga didapat spesifikasi desain yang ditunjukan oleh tabel 1

TABEL I. SPESIFIKASI SASIS MOBIL URBAN

\begin{tabular}{|l|l|}
\hline \multicolumn{2}{|c|}{ Spesifikasi sasis } \\
\hline Rangka Samping & $1830 \mathrm{~mm}$ \\
\hline Rangka Silang & $420 \mathrm{~mm}$ \\
\hline Dudukan Pengemudi & $420 \mathrm{~mm}$ \\
\hline Tinggi Sandaran pengemudi & $600 \mathrm{~mm}$ \\
\hline Lebar Body bagian belakang & $1040 \mathrm{~mm}$ \\
\hline Lebar Body bagian depan & $480 \mathrm{~mm}$ \\
\hline Tinggi dudukan as roda belakang & $140 \mathrm{~mm}$ \\
\hline Tinggi dudukan as roda depan & $160 \mathrm{~mm}$ \\
\hline Wheelbase & $1250 \mathrm{~mm}$ \\
\hline Tinggi Dudukan batang stir & $378 \mathrm{~mm}$ \\
\hline Lebar penghubung as roda depan & $760 \mathrm{~mm}$ \\
\hline
\end{tabular}

Berdasarkan hasil desain menggunakan software solidwork dan telah didapat dimensi sasis, selanjutnya dalah proses manufaktur sasis, hal tersebut ditunjukan pada gambar 3, sasis tersebut disatukan dengan las alumunium dan beberapa komponen sasis yang keperluanya untuk bracket sistem penggerak menggunakan baut dan nut.

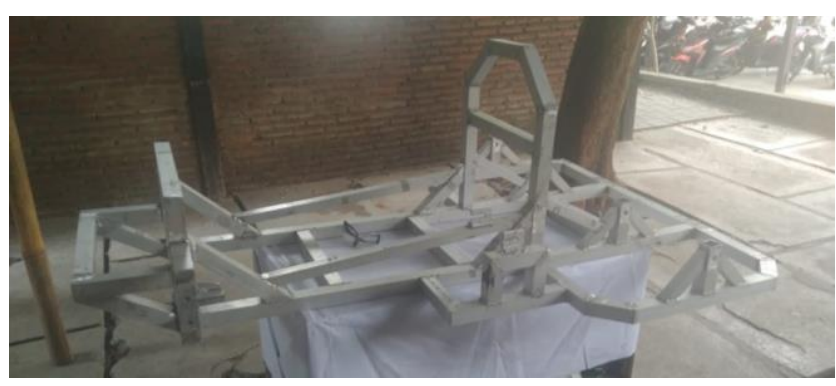

Gambar 3. Hasil manufaktur sasis berdasarkan desain
Pada gambar 4 merupakan sasis setelah dilakukan proeses pengecetan pada frame utama dan dirakit dengan roda beserta sistem pengereman yang menggunakan sistem hidrolis

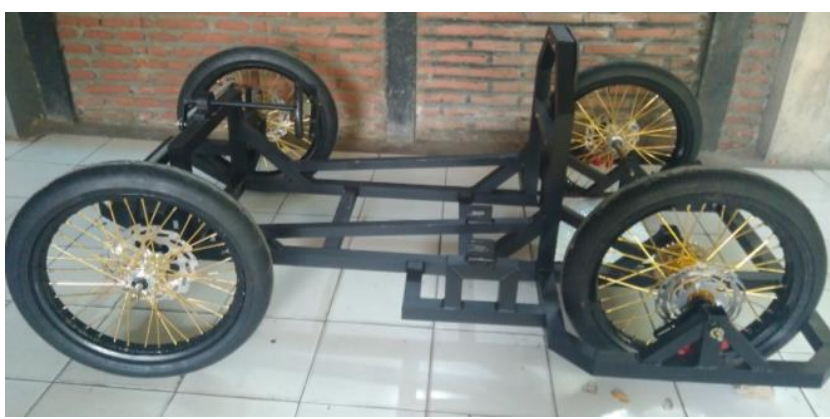

Gambar.4 Manufaktur sasis dengan roda

\subsection{Sistem Penggerak}

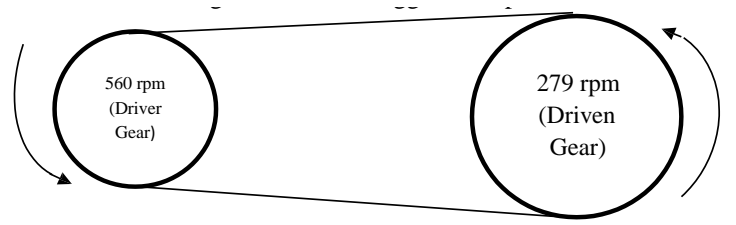

Gambar.5 rasio gear transmisi

Pada gambar 5 menunjukan rasio gear pada transmisi kendaraan listrik, pada sisi putaran penggerak memiliki kecepatan $560 \mathrm{rpm}$, sedangkan pada sisi putaran roda memiliki kecepatan $279 \mathrm{rpm}$

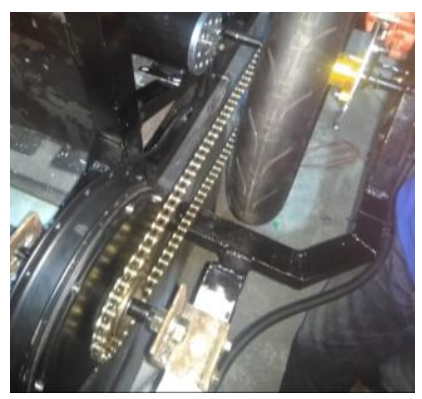

Gambar.6 pengimplementasian desain transmisi

Gambar pengimplementasian rasio gear yang sudah dirakit pada sasis di sistem transmisi dari penggerak utama ke roda ditunjukan pada gambar 6, pada transmisi kendaraan menggunakan single line transmission, yang berarti gear motor BLDC dihubungkan langsung dengan gear yang terhubung pada roda menggunakan rantai. Spesifikasi penggerak utama motor BLDC 1000 watt ditunjukan pada tabel 2. 
TABEL II. SPESIFIKASI MOTOR BLDC

\begin{tabular}{|l|l|}
\hline Spesifikasi Motor BLDC \\
\hline Tegangan & $48 \mathrm{~V}$ \\
\hline Power Watt & 1000 Watt \\
\hline Over Power Watt & $>1000$ Watt \\
\hline Amper Kerja & $16-18 \mathrm{~A}$ \\
\hline Over Amper Maks & $>35 \mathrm{~A}$ \\
\hline Torsi & $30-50 \mathrm{Nm}$ \\
\hline
\end{tabular}

Perakitan sistem penggerak utama ditunjukan pada gambar 7 , pada gambar tersebut motor BLDC dipasang pada sasis yang sudah terinstal dengan rodan dan sistem rem serta baterai lithium-ion 48 volt 8.7 ampherehour, controller, dan trottlel injak

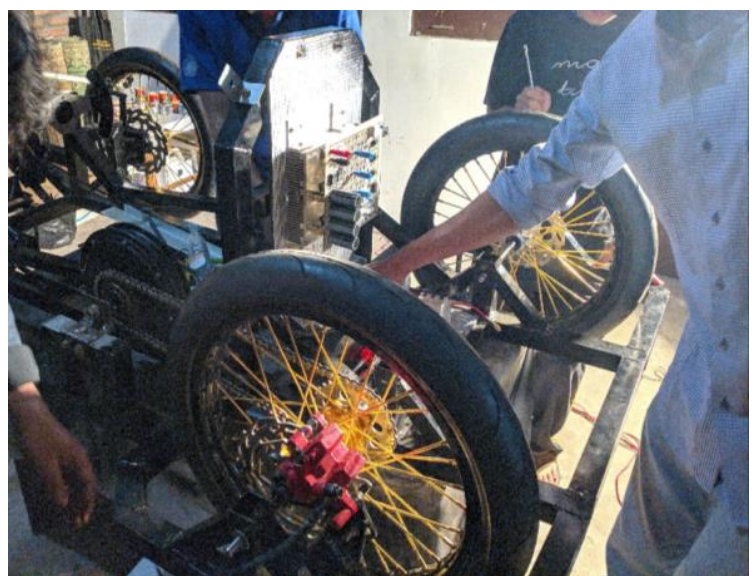

Gambar .7 pemasangan sistem penggerak pada sasis

\subsection{Baterai}

Sumber energi yang digunakan adalah baterai dengan kapasitas 48V /8,7 Ah, yang tersusun dari baterai jenis li - ion, gambar 8 menunjukan manufaktur baterai

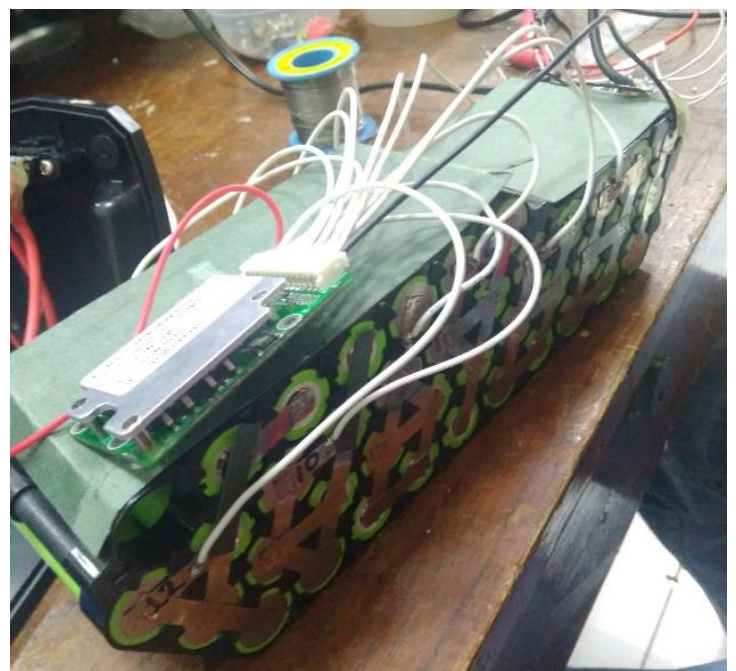

Gambar.8 Manufaktur Baterai
Baterai tersebut tersusun atas seri dan pararel untuk menghasilkan tegangan $48 \mathrm{~V} / 8,7 \mathrm{Ah}$, cara menentukan perakitan tegangan $48 \mathrm{~V}$ adalah penyusunan baterai secara seri untuk mendapatkan tegangan $48 \mathrm{~V} 48 \mathrm{~V} / 3.6 \mathrm{~V}=13$ tersusun seri. Baterai seri 13 cell untuk mendapatkan kapasitas 8,7Ah dengan mempararelkan baterai $10 / 2.7=4$ tersusun pararel. Untuk keamanan rangkaian baterai dilengkapi dengan BMS 25A, Keamanan beban menggunakan sekring untuk melindungi komponen beban dan sumber baterai, serta pada peletakan baterai pada sasis ditunjukan pada gambar 9 .

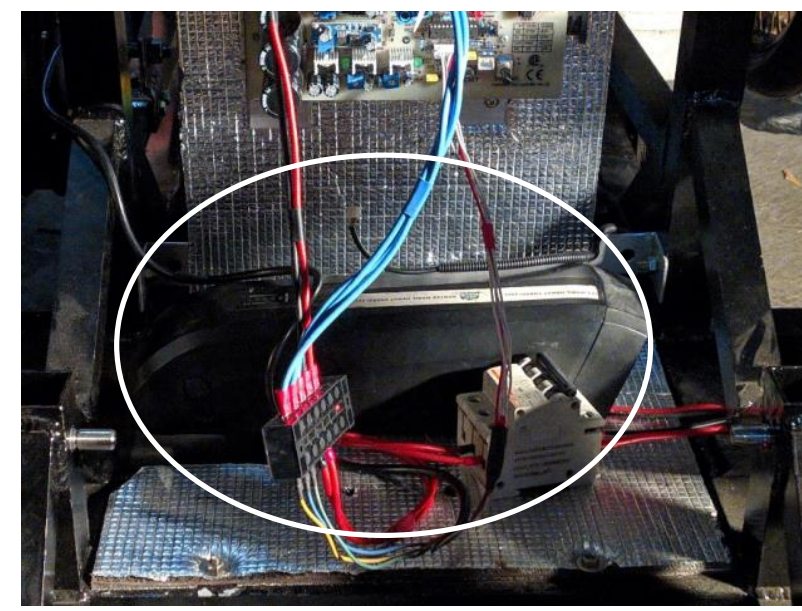

Gambar. 9 Peletakan Baterai pada Mobil Urban

\subsection{Simulasi pembebanan sasis}

Hasil yang didapat pada beban total kendaraan di tambah beban driver dengan total yaitu sebesar 1254,4 N. Gambar 10 menunjukan hasil simulasi kekuatan chassis untuk mengetahui kekuatan rangka dalam menahan beban secara horizontal.

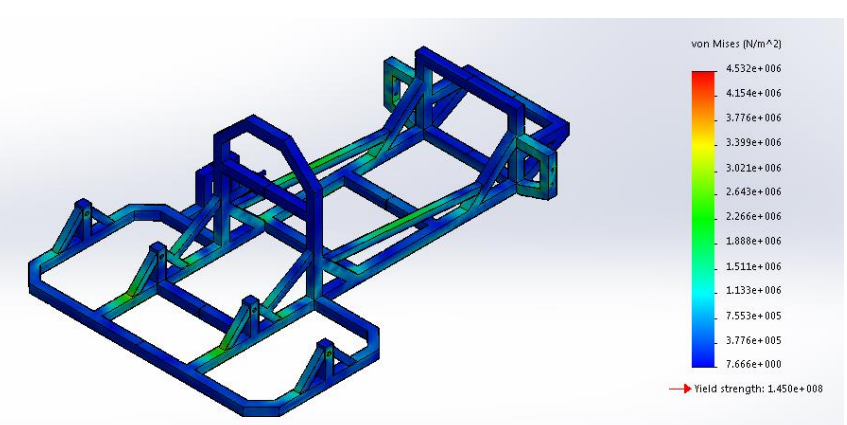

Gambar 10. simulasi tegangan pada beban total 1254,4 N

\subsection{Perakitan Keseluruhan}

Perakitan secara keseluruhan komponen dilakukan setelah dipastikan bahwa semua komponen-komponen telah berhasil bekerja dengan baik, komponen tersebut adalah sasis, sistem penggerak, sistem roda dan pengereman sistem kemudi, sistem transmisi serta dudukan untuk pengemudi, dari perakitan semua komponen secara keseluruhan didapat luaran kendaraan 
listrik yang utuh, gambar 10 menunjukan perakitan semua komponen dari kendaraan listrik.

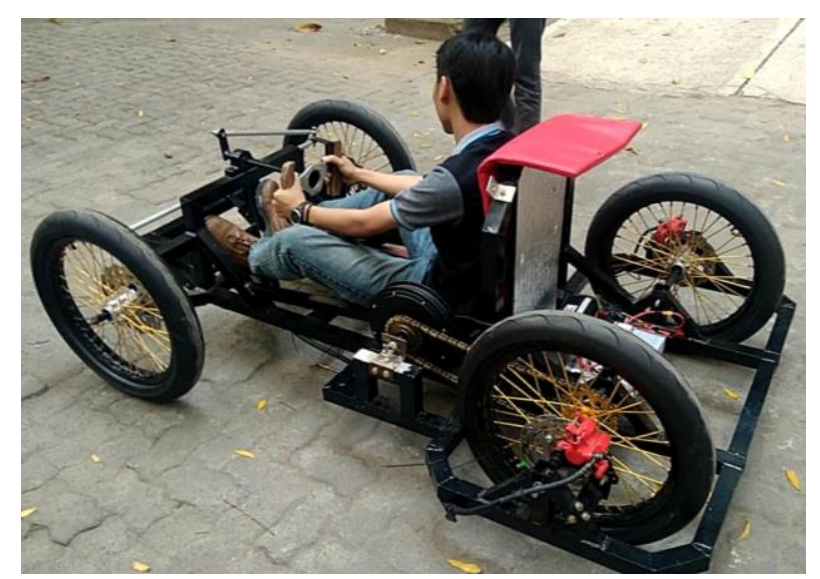

Gambar. 11 perakitan sasis \& sistem penggerak

\section{KESIMPULAN}

Penelitian berhasil dilakukan sesuai dengan metode yang direncanakan, dari tahap perencanaan desain kendaraan yang meliputi desain chasis, sistem penggerak, dan baterai. Setelah konsep desain berhasil, dilakukan pengimplementasian desain, setelah masing-masing dari sistem telah berjalan dengan baik, selanjutnya dilakukan perakitan semua komponen yang telah dimanufaktur, sehingga didapat luaran hasil kendaraan listrik yang utuh

\section{DAFTAR PUSTAKA}

[1] http://www.bps.go.id. 12 Agustus 2019

[2] http://bphmigas.go.id/konsumsi-bbm-nasional. 12 Agustus 2019

[3] Larminie, James \& John Lowry. 2012. Electric vehicle technology explained . A John Wiley \& Sons, Ltd., Publication

[4] Kennedy, Rankin .1905. The Book of Modern Engines and Power Generators. Vol I. London: Caxton. p. 33

[5] Gas-powered vs. Electric Cars: Which Is Faster?". How Stuff Works. 15 January 2019.

[6] Vogel, Carl . 2009. Build Your Own Electric Motorcycle . The McGraw-Hill

[7] T.G. Wilson, P.H. Trickey, "D.C. Machine. With Solid State Commutation", AIEE paper I. CP62-1372, October 7, 1962

[8] Azizi, N and Moghaddam, R.K. 2013. Permanent magnet brushless DC motor optimal design and determination of optimum PID controller parameters for the purpose of speed control by using the TLBO optimization algorithm. American Journal of Research Communication, vol. 1, no. 1, pp. $294-313$. 